\title{
Correction to: High frequency multiscale relationships among major cryptocurrencies: portfolio management implications
}

Walid Mensi ${ }^{1,2^{*}}$, Mobeen Ur Rehman ${ }^{3}$, Muhammad Shafullah ${ }^{4}$, Khamis Hamed Al-Yahyaee ${ }^{5}$ and Ahmet Sensoy ${ }^{6}$

The original article can be found online at https://doi. org/10.1186/s40854-02100290-w.

\section{*Correspondence:}

walidmensi1@gmail.com

${ }^{1}$ Department of Economics and Finance, College of Economics and Political Science, Sultan Qaboos University, Muscat, Oman Full list of author information is available at the end of the article

\section{Correction to: Financ Innov 7:75 (2021) https://doi.org/10.1186/s40854-021-00290-w}

Following publication of this article (Mensi et al. 2021), the corresponding author reported that his 2nd affiliation was missing.

So the corresponding author's affiliations are:

${ }^{1}$ Department of Economics and Finance, College of Economics and Political Science, Sultan Qaboos University, Muscat, Oman

${ }^{2}$ South Ural State University, 76, Lenin Prospekt, Chelyabinsk, Russian Federation

The affiliations have been updated in this Correction and in the original article.
Author details

${ }^{1}$ Department of Economics and Finance, College of Economics and Political Science, Sultan Qaboos University, Muscat, Oman. ${ }^{2}$ South Ural State University, 76, Lenin Prospekt, Chelyabinsk, Russian Federation. ${ }^{3}$ Shaheed Zulfkar Ali Bhutto Institute of Science and Technology (SZABIST), Islamabad, Pakistan. ${ }^{4}$ School of Economics, University of Nottingham Malaysia, Jalan Broga, 43500 Semenyih, Selangor, Malaysia. ${ }^{5}$ Muscat University, Al Ghubrah North, Muscat, Oman. ${ }^{6}$ Faculty of Business Administration, Bilkent University, 06800 Ankara, Turkey.

Published online: 29 October 2021

Reference

Mensi W, Rehman MU, Shafiullah M et al (2021) High frequency multiscale relationships among major cryptocurrencies: portfolio management implications. Financ Innov 7:75. https://doi.org/10.1186/s40854-021-00290-w

\section{Publisher's Note}

Springer Nature remains neutral with regard to jurisdictional claims in published maps and institutional affiliations. author(s) and the source, provide a link to the Creative Commons licence, and indicate if changes were made. The images or other third party material in this article are included in the article's Creative Commons licence, unless indicated otherwise in a credit line to the material. If material is not included in the article's Creative Commons licence and your intended use is not permitted by statutory regulation or exceeds the permitted use, you will need to obtain permission directly from the copyright holder. To view a copy of this licence, visit http:// creativecommons.org/licenses/by/4.0/. 